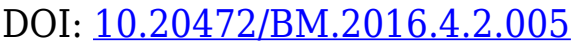

\title{
GENERATION Y ON THE JOB MARKET. YOUNG POLES' EXPECTATIONS OF JOB AND EMPLOYER - RESULTS OF RESEARCH.
}

\section{IZABELA STAŃCZYK, ANETA PIECZKA}

\begin{abstract}
:
This study refers to the $Y$ Generation's expectations of the job market. This generation is challenging for employers who want to attract good employees and retain them in an organization. Many public discussions touch this issue and talk about Generation Y's claims and exaggerated aspirations; employers complain about high expectations and lack of communication with older employees. This generation is the first which has grown up in the world of technology and computers and is totally absorbed by the Internet and virtual world. It represents different than previous generations' life priorities, different skills and needs. These particular factors that affect young people's attitude were included in this study.
\end{abstract}

\section{Keywords:}

generation Y, communication, culture, job market, candidates' expectations of job, human resources management

JEL Classification: $J 24$

\section{Authors:}

IZABELA STAŃCZYK, Institute of Economics, Human Resources Management Department, Jagiellonian University, Poland, Email: izabela.stanczyk@uj.edu.pl ANETA PIECZKA, Jagiellonian University; pieczka.aneta@gmail.com,, Poland, Email: pieczka.aneta@gmail.com

\section{Citation:}

IZABELA STAŃCZYK, ANETA PIECZKA (2016). Generation Y on the job market. Young Poles' expectations of job and employer - results of research.. International journal of Business and Management, Vol. IV(2), pp. 56-70., 10.20472/BM.2016.4.2.005 


\section{Introduction}

Generation $Y$ is just entering the job market. However, in several years it will be numerically dominated in organizations. According to the Deloitte report, Generation $Y$ (in this case defined as people who were born after 1982) in 10 years will represent $75 \%$ of the labour force (www.polskieradio.pl). According to R. Dryla, Managing Director at GP People Employment Agency, the young generation „learns quickly but also quickly gets bored, approaches great international projects without complexes but does not attach to the current workplace" (www.hrtrendy.pl). People representing the $\mathrm{Y}$ Generation are creative and ambitious but difficult to manage. Only by understanding Millennials' mentality, employers can attract, motivate, train and retain them in the company (Sheahn, 2005; Armour, 2013). When facing this situation on the job market, one should learn what are the competences of young people and their expectations of future employer.

\section{Generation Y definition}

To define Generation Y, there should be reference to previous generations which wouldallow to indicate the differences. Prior to the $Y$ Generation was Generation $X$ and earlier, the Baby Boomers Generation. Generation X represents today 40-years-olds, born between 1965 and 1980. These people were born during the moral revolution, when individualism and self-reliance (not collectivism as in case of previous generation) became values. This generation is often described as seeking the meaning of life and existence. The problem, this generation deals with is a change in employment system. Work is no longer characterized by long period of employment (www.wiedzaiedukacja.eu). To reach a good proffesional position, they often work very hard, they do not want to count on their parents' help. They are familiar with technologies but Internet and technological innovations are not the most important for them. Altough they lead a consumption lifestyle, they know the value of money which they have worked hard for. The Baby Boomers Generation reffers to people born after the Second World War to the 60 s of $X X^{\text {th }}$ century during the population boom. This generation is currently represented by people in retirement or pre-retirement age. Born in the culture of patriarchy, they perceive the world as a vertical structure. They are for the traditional division of roles where women are housewifes and men earn the money. Having grown up in communism, they think that everything shared is mine, they are also quite suspicious and distrustful of others. These are people who are afraid of losing their jobs and often believe that to be rich, you need to cheat (www.mateuszgrzesiak.natemat.pl).

The generation which is currently entering the job market or working for several years isthe $Y$ Generation. It raises a lot of excitement and controversy due to the specific attitude towards life and work, different than the earlier generations represented. Before we decide to evaluate, one should firstly look at experiences shared by these people 
which are connected to the century they live in and which helps to understand young people's behaviour. According to U. Kosa and D. Strzelec, the most important experience shared by Generation $Y$ is:

- Growing up in a free market economy,

- Constant connection with new technologies,

- Increasing standard of life and consumption,

- Broad choice of career,

- Mobility - easy travelling,

- Contact with other cultures,

- Virtual life - Internet, virtual society, meeting and staying in touch with people on the other side of the world,

- Quick pace of life, dynamic changes, doing several things simultaneously, multitasking,

- Striving to meet own needs, self-realization, individualism (Stańczyk, 2013, s. 65).

The corporation which regularly conducts the research related to world economics issues, including the labour market, is Deloitte. In 2014, Deloitte conducted research called „The Deloitte Millenials Survey" in 26 countries around the world. The questionairre was filled in by 7600 young people and on this basis the report was created (www.deloitteegitimvakfi.org.tr). The title of the report indicates main trends and results: Big demands, high expectations. These are the main conclusions from the study:

- Innovation is more expected from business than academic institutions and government.

- Most representatives of Generation $Y$ think that are not awarded for innovative thinking and questioning status quo.

- Nearly three-quarters of respondents want to work independently.

- According to ther $Y$ Generation, major challenges of the next few years will be unemployment, shortage of resources, climate changes, income inequality.

- For the $Y$ Generation, it is important to find an employer who rewards and promotes innovation as well as gives the opportunity to develop leadership skills.

- Entering the job market, Millennials recognize a lack of their communication skills (assertiveness, negotiating) and specific job competencies connected with law, finance, IT, taxes.

Similarly, PWC conducted a survey in 2011 related to the $\mathrm{Y}$ Generation and its expectations of job „Millenials at work. Reshaping the workplace“. The study involved more tan 4 thousands graduates in 75 countries. Here are the highlights from the research: 
- Representatives of the $Y$ Generation, opposite to previous generations, feel less loyalty to their employer. They expect between 2 and 6 and more employers during their career.

- Development and work-life balance is more important than earnings which are in $3^{\text {rd }}$ place.

- Millennials expect cultural diversity in the workplace while being disappointed with the lack of it.

- Representatives of the $Y$ Generation believe that access to technology causes more work effectiveness, some of them even prefer electronic contact than face to face. However, according to them technology is often the cause of conflict between generations in the workplace and thus Millennials feel inhibited by stiff and outdated ways of working.

- For Generation Y, climbing the career ladder is very important, what is more, the career path determines the attractiveness of the employer.

B. Kasalová, K. Seitlová and M. Seitl studies show that students prefer flexible working hours, work in international teams thereby increasing your creativity. They also want to have a concrete description of the tasks and adequate pay. (http://web.a.ebscohost.com).

In contrast, studies by Šnýdrová, Markéta (2014) show that employers must change the approach to the acquisition of new, young people from the labor market: „The results of the investigation indicate the need for changes in the approach to the staff, not only in the use of modern technologies and methods (in particular social networking), but also in the benefits package offer. The results further suggest that the basic requirement of the Generation $Y$ members is to be seen by the employer as partners, who provide their competences and creativity in exchange for the evaluation required, including the benefits, inclusive flexibility and the opportunity for the career growth and development."

S. Banerjee draws attention to the greater mobility of workers from Gen $Y$ than a generation earlier (http://web.b.ebscohost.com/bsi/).

Allen C. (2007) in KPMG conducted a study on the labor market in countries such as Germany, Japan, UK, US and Australia among young people of the generation Y. Despite the cultural differences in the report stated that „overall, though, Gen $Y$ workers tend to be well educated, demanding, want rapid professional recognition and show little commitment."

Other observation in the study of Gen $Y$ and the labor market saw Bhonlay M. (2007). "The author discusses that this generation is extremely computer savvy, however; a major problem facing employers is training and developing these workers. The author also notes that while this generation makes up the majority of retail employees, many are reaching positions of responsibility far faster than previous generations." 


\section{Generation $Y$ on the job market - results of own research}

The research was conducted in the first half of 2015. Respondents were born between 1985 and 1995, all of them are polish citizens, mostly living in Krakow. The study is divided into two parts - a survey including 129 young Poles and a focus group of 9 respondents.

The main objective of the research was to identify the expectations of young people who are just entering the job market. The study was intended to answer the following questions:

- Which job would fit you the best?

- What is the most important while choosing an employer?

- Which work mode is the most attractive?

- What kind of reward do you expect?

- Is the loyalty to the employer still valuable?

- What do you expect from the employer?

- What is the current situation of the job market in young people's opinion?

Sampling was based on the availability of respondents. This model is called non probabilistic and even if correct, does not guarantee that the observed group is representative of the population so one who analyzes the results should be careful to generalize the conclusions drawn from the study. This method is easy to handle and low cost. (Babbie, 2003).

The first technique was a questionnaire - this is used when the population is too large to observe it directly. In many cases questions were open to provoke respondents to deeper reflection and raise some kind of interaction. There were also used some closed questions because these answers characterized higher uniformity. The research was conducted by using CSAQ method - Computerized Self-Administered Questionnaire; respondents received the questionnaire via the Internet platform and the asnwers were collected on this platform.

The survey respondents represent different status, ranging from daily students, through extramural students to graduates who currently work. All subjects have already had work experience, at least in the form of internship or apprenticeship. When asked about their dream job, most of them indicate running their own business which was followed by proffesions such a traveler, manager and work in a creative business. Such responses confirm strong individualism and a desire to be independent.

While choosing an employer, the most important thing is money (83,7\% of respondents) but almost the same number indicated workplace atmosphere as an important factor 
$(80,6 \%)$, as well as development prospects $(66,7 \%)$. Only at the subsequence places are promotion prospects, benefit packages or company positions in the market (could be indicated 3 the most mattering factors). Young people appreciate above all work in friendly environment and development of their skills.

A very remarkable trend which supposed to differ Generation $Y$ from the previous ones is the favoured mode of work. Regarding new technology development, flexible forms of work are increasingly gaining popularity, for instance task-oriented work or teleworking. The traditional 8-hours/day of work is considered to be less efficient and less attractive what is presented in Table 1.

Table 1. Respondent's answer to the question: „Which system of work is the most attractive in your opinion?"،

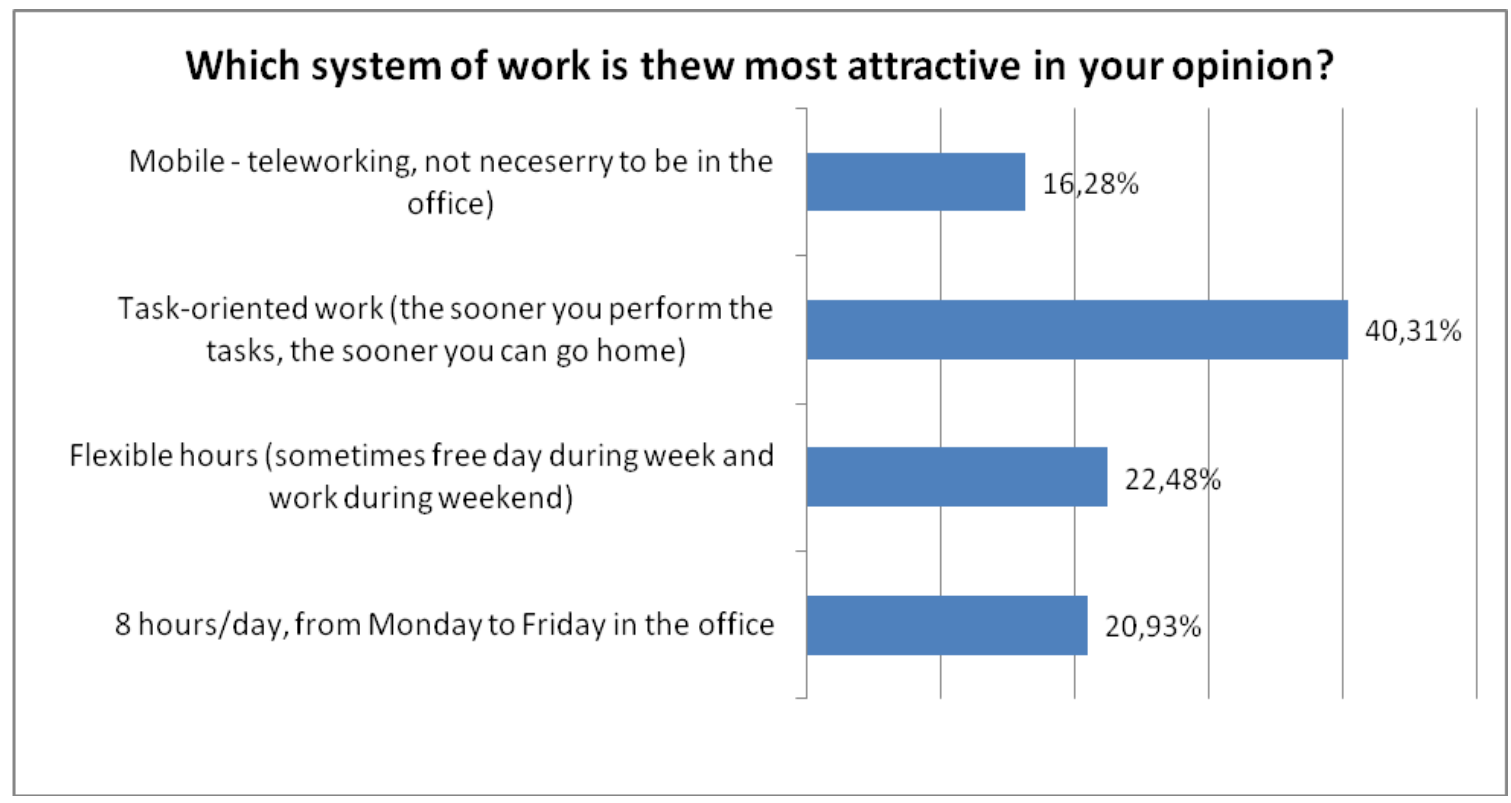

Source: own study

The choice related to the dream job that was presented in first question is also confirmed by the next question related to the type of the company which young Poles would like to work for. 
Table 2. Responses on the question: „What type of company would you prefer to work for?"“

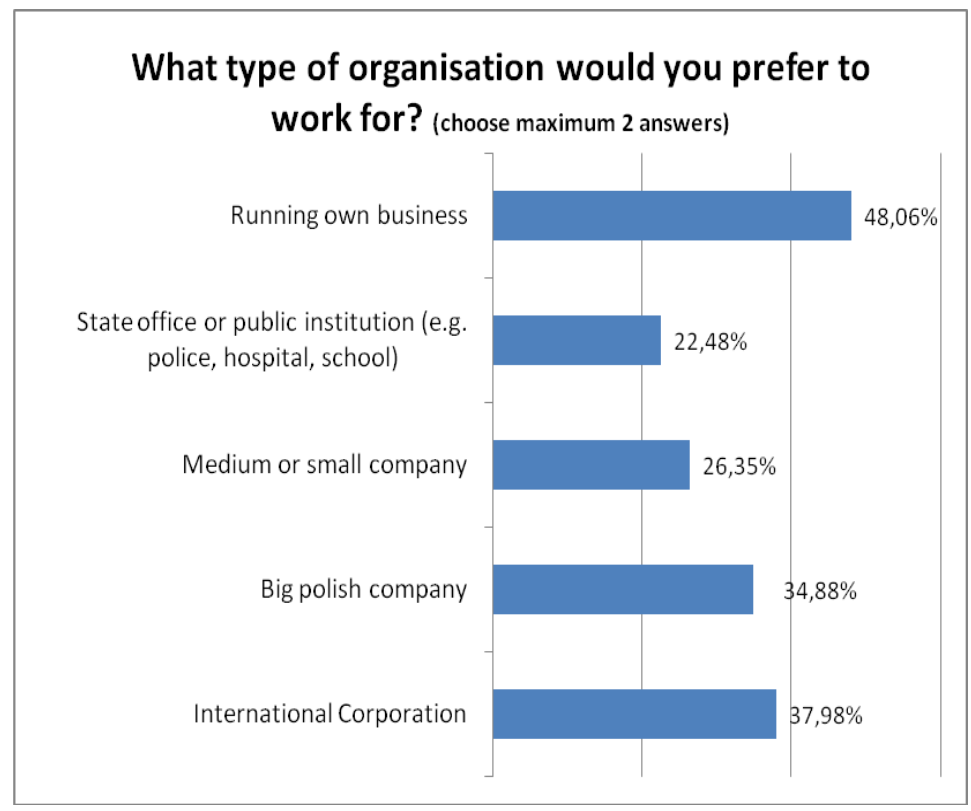

Source: own study

Most of them would prefer to run their own business (48\%), while the second place was work in a large, international corporation (38\%). The least popular option is work in a state office or public institution (22,5\%). This is a particular sign of the times, as several dozen years ago, working for a state office in Poland was perceived as prestigious and distinguished. Nowadays, this tendence has turned towards independent business or work for an international company.

An interesting question of the study was: "What would you choose: a boring and well-paid job or an interesting but poorly-paid job?". It turns out that the answers are divided almost symmetrically, half of respondents chose the first answer and half chose the second one which is illustrated by Table 3 . This is, in fact a noteworthy trend, because it should be pointed out that up to half of the people chose an interesting but not a well-paid job. If asked the same question to Generation X or Baby Boomers, the answers might be composed differently - more indications care for a well-paid but boring job. 
Table 3. Respondents' answer to the tricky question of choice.

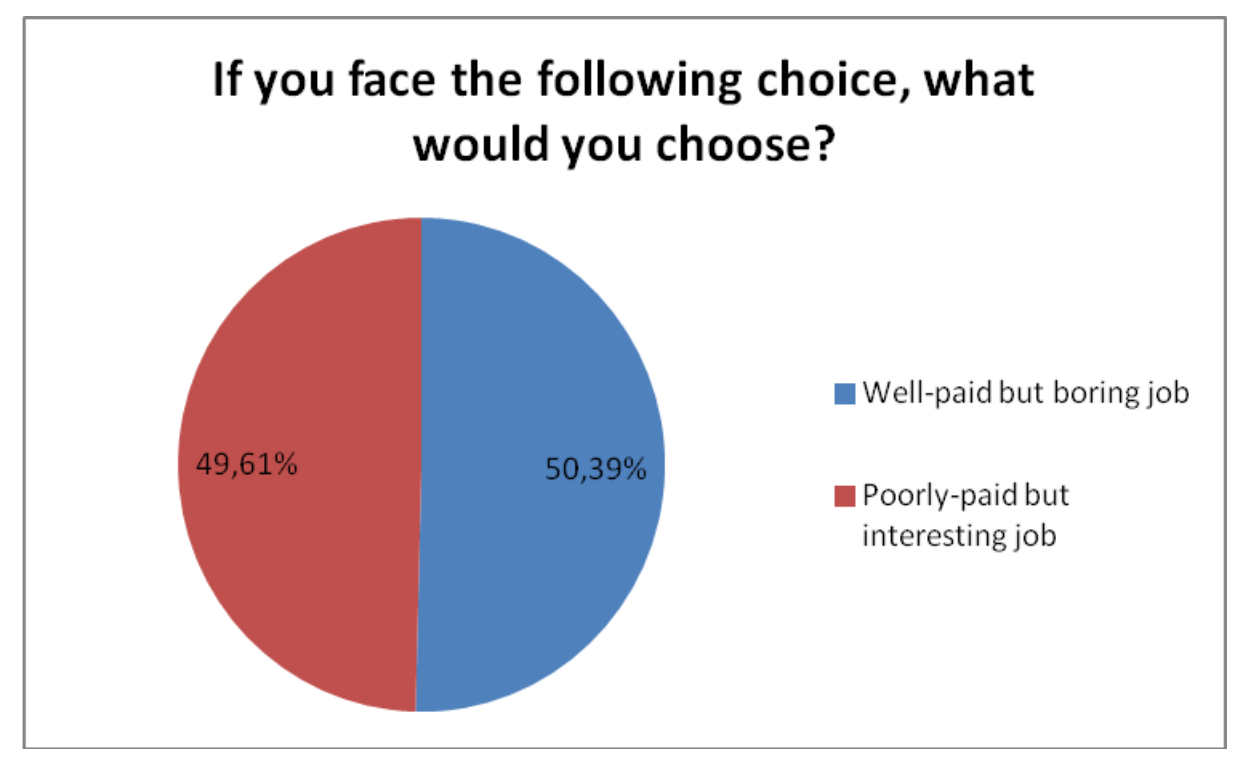

Source: own study

The relevant feature which is a good illustration of Generation $Y$, is the approach towards changes. For Millennials change is not a reason for concern but they mostly consider it a challenge $(65 \%)$ and identify with improvement (51\%). Only 3,8\% of subjects think that change is associated with a deterioration of the situation. The approach towards changes will turn out to be a key aspect and motivation for less loyalty of young people to their employers or occupation. Most of them believe that their job should be changed every few years, even assuming the current is satisfying. A third of respondents think that they can work in the same role from 1 to 3 years, almost $30 \%$ assume from 3 to 5 years.

As indicated by the results of the research, an ideal employer is not the employer for ages (only $7 \%$ of respondents think so) but primarily the employer who gives opportunities and sets challenges.

Moving to the matter of remuneration, for the $Y$ Generation earnings are relevant but young people are aware that entering the job market, they do not have the appropriate skills and competencies yet, that is why most of them are able to work for free or for low pay for a while. The purpose of internships and apprenticeships is to broaden knowledge, raise awareness and gain experience. This might be important information for people who set up a compensation system in the organisations. 
Table 4. Respondents' answers rergarding years of work in the same role.

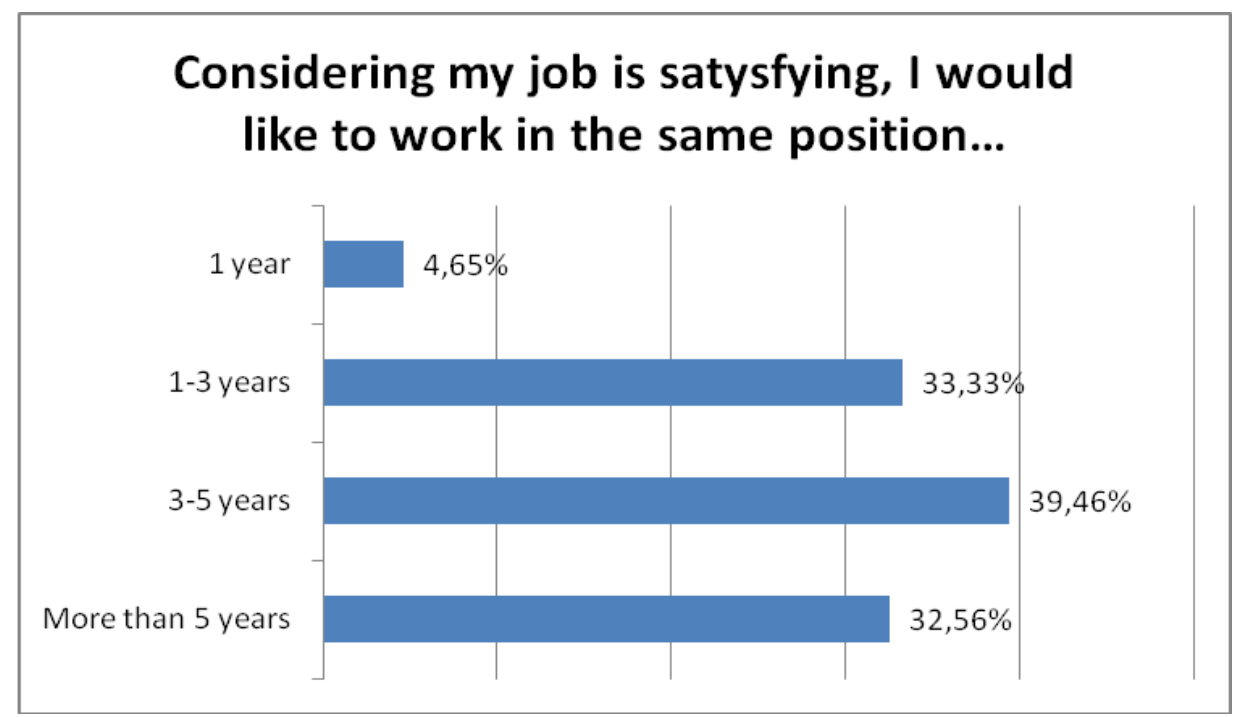

Source: own study

\section{Focus group interview}

The second study which helped to crystallize results from the survey, was a focus group interview. 9 individuals representing different status met during a discussion panel to talk about their experience and preferences. The group consisted of IT specialists, financiers, engineers, students of biology, economics and science. The oldest person was 29 years old and the youngest 22. All of them have previously undertaken professional activity.

The interview took the form of free but standarized discussion and was combined with participants observation, everything lasted less than 1 hour. Previously prepared questions and a set of issues were used as a hint to moderate the interview. The conversation was dynamic and intensive and thanks to that some issues raised which were not planned in the concept.

Discussions started from the issues of part-time work. It turns out most of the participants undertook diverse odd jobs while studying. They were for instance, manual labourers, bar work, shop assistants, in call centres, running a family business, working at a petrol station. The respondents much appreciated such experiences as it lets them develop many additional skills which are not practised while studying at univerisity such a familiarity with company life. One of the participants, a biology student says: „The job taught me respect for other people, for instance people working in the cinema or at hotel because once I had worked in those places". Another student of economics presents 
similiar point of view: „Once you work physically it is easier to treat people who work in such areas with respect".

The next issues discussed were the expectations of the employer. Participants indicated the approach to the employee as an important factor. The thing which matters the most are trust and freedom to act because it results in better efficiency.

An other important point is being (as an employee) the foundation of a well-functioning organisation. Respondents emphasized they counted on investing in themselves and setting human capital in the first place. What is interesting, no one raised the issue of wages or salary.

The subject of intense discussion, was the mode of work preffered by participants. Young people decreasingly appreciate the stability and fixed hours of work. They are able to work more than 8 hours a day if a project requires, while on another day, work less if they perform all the tasks quicker. Organisations that offer more autonomy and self-managing possibilities will be evaluated better by Millenials and will be more likely selected for the job.

The participants of the focus group interview find work for free as a very popular practise in Poland. First of all, students take part in an obligatory apprenticeship during their studies (usually 4 weeks or more) where they are not paid. However, they answer almost unanimously they would be able to work for free as long as that work provided them with good experience and career investment. One of the respondents notices: „It depends on the carrer stage. In the beginning, when you don't expect much, this form of employment is fine but if I made a coffee I would say no". Is there anything more, apart from salary, which motivates Millennials? It turns out to be that. As a highly individualistic generation and often educated in stress-free conditions, attaches great importance to prestige and requires being rewarding. One of the participants values the reward in the form of verbal praise: „you did very well, thank you“. Another respondent talks about a similar award: "good recommendations on websites such a Linkedin“. Participants agree that praise works better than punishment, which can discourage further work.

Nowadays, the subcject of wide public discussion is young people's situation on the labour market in Poland. There is much talk about an unfavourable work situation. According to research, it is hard to find a job for this group. This issue commented by one of the focus group participants: "The situation in big cities is good and even very good because if you compare it to the rest of world, taking into account economic growth, inflow of investment and corporations or direct investments, in big cities in Poland the situation is excellent. People can assess it differently but on a global scale our situation is really good. We can pick offers. In smaller towns the choice is unfortunatelly limited". He says also: „Look at the finance industry, if there is a lack of candidates with financial or maths background, people with humanistic education are hired, they are trained and can 
work with numbers". Regarding small towns, another respondent sums up the situation: „In smaller towns it is very hard to find a job. People work for a long time in the same position and there is no rotation". Young people seem to be aware of the current situation and look at that with optimism.

Representatives of the $Y$ Generation who were questioned about their willingness to work abroad, agree that they consider such an option. However, not only because of money but mostly due to a desire to travel and develop themselves: „In my opinion, to avoid our departure, the world would have had to be standarized and unified, I mean a unified language, people's attitude, then there would be no curiosity about the unknown. But as long as each country is different and the world is so diversified, people are simply curious" - this opinion is presented by a student of economics who works in a HR department and is thinking about moving abroad.

Millennials eagerly relate to changes, which confirms the survey research, „I am not able to work in the same position for a long time, I am supposed to do something new, except this position is extremely varied" - notes the participant. A relevant aspect was also raised by another respondent, an IT Specialist: „Every change of work is like leaving the comfort zone, usually you need to have really strong arguments to change work, e.g. higher salary". This is the other side of the coin which shows that not for everyone change is so obvious but should be determined by external factors. Although, while asking whether the respondents would imagine working in the same position for 20 years, the answer was unanimous: „definitely not!".

\section{Research summary}

To sum up the research, three expressions can describe Generation Y: change, challange and work-life balance. Change is something completely natural and even permanent and this factor sets them apart from previous generations. Millennials feel the desire for challenges and they would like to have an interesting job that gives them not only a good salary but also possibilities for personal development. Work-life balance is a relatively new preference. In Millennials' opinion, work is important but is no longer of key importance in life, they want to combine work with passion and have enough time to carry out non-business plans.

Young people seem to be aware of the labour market situation, they undertake parttime work and internships during their studies. As results of the research, they do not expect much at the beginning - they want to learn, absorb knowledge and develop skills. When they become experienced, their expectations increase and attitude is more demanding - they feel they have something to bring to the organisation, therefore they feel worthy of greater earnings. While starting the career, young people don't expect much and are happy about even the lowest salary. When they gain experience, the 
expectations grow at a fast pace. Hence the general opinion about Millenials as demanding and pretentious.

Both research, survey and focus interview confirm that Generation $Y$ appreciates work in friendly atmosphere based on partnership - this is relevant factor while choosing an employer. They expect stimulating conditions for their development needs which sometimes are more important than money. Young people believe this culture is conducive to better results and effective performance of the tasks.

The important issue for the Millenials is a mode of work. Not everyone wants to work anymore in a traditional 8-hours system. Nowadays, the more flexible working hours and workplace are, the better you work. All modern methods such as home office, taskoriented mode are welcomed by Generation Y. In these young people's conception, good performance of the task should provide a basis of pay, not the amount of time spent in the office.

It is also worth mentioning the approach to change amoung young people. As indicated earlier, for them change is something natural and they associate change with a new challenge. Thus, Generation $Y$ is oriented to a frequent change of position or company. They expect to be developed and if this need is not met, they begin to look for new opportunities outside the company they work for. The barrier of leaving the comfort zone becomes less influential. Development is more important and it mobilizes them to make efforts to find a better job. Loyalty to the company is no longer the main value. The value now means new challenges, change and learning.

Many young people consider moving abroad which is linked to labour market situation. According to Central Statistical Office in Poland, currently about 2 milion Poles stay abroad for work purposes (http://www.polityka.pl). The research confirms a survey conducted by Centre for Public Opinion Research which informs that about a third of Poles aged 18-24 consider moving abroad to work (http://www.polityka.pl/tygodnikpolityka). However, young people differ in their opinion of the general situation in the job market. Some of them believe the situation is fine as long as you are qualified enough and possess the appropriate skills. On the other hand, many of them consider the current situation bad as indicated by percentage of subjects willing to departure.

\section{Conlusion}

Considering reaserch results regarding Generation $Y$, companies should focus on a few areas to enhance their image among Millennials, attract them and create the best staff. The leaders (i.e. major corporations) do it now - they modify HR policies to be the most interesting for young generation. This makes really forward-thinking firms obtain most 
talents. Generation $Y$ is aware of what the market offers so it chooses the companies which have the most to offer and attractiveness is affected not only by the financial factors but also a range of other factors.

For example, here are the recruitment practices that companies should focus on:

- Create an exact and comprehensive job description and requirements in the advertisement. It inspires trust during the first stage of contact with the company.

- Specify the recruitment phases at the beginning. Transparency is an important advantage for young people who thanks to this might feel partnership approach.

- Define the career path in the position the candidate applies for. Thereby it is easier to encourage or avoid disappointment and excessive expectations.

- Indicate pay ranges at the initial stages of recruitment. Openness encourages trust.

- Build positive relationship with candidates. Even if the candidate is not offered, the company should stay in touch with the candidate which allows for applying in the future.

- Test the candidate by the recruitment tasks which show factual knowledge and skills. Young people expect ambitious tasks to show what they can do and fair assessment.

- Feedback to the candidates including negative response. Providing the information which skills should be improved.

Generation $\mathrm{Y}$ is significantly different from previous generations. Although, it is not homogenous inside but some characteristics apply to almost every representative. First of all, it is open to changes and willing to apply them, being not afraid of challenges and innovations. This feature results in a completely different approach to work than the predecessors represent. Today, the twenties have grown up when new technologies were becoming widely used, for this reason the virtual world and new work tools are not strange - they know how to use them and quickly process the information. This makes them impatient and when communicating with older people they may seem arrogant. In addition, Millennials from Poland do not much differ from their western peers because they were brought up in an independent Poland. They communicate in various languages, travel around the world and possess wide general knowledge, learnt from the Internet. Their life was not full of sacrifice and suffering, hence the frequent demanding attitude and the desire to be praised.

Although young people are extremely demanding, it is important they are able to contribute as much to the organization they work for. Values such as openness, communication, creativity and making changes are crucial. From our point of view, companies with the appropriate personnel management are able to use the potential of employment of young people as never before. 


\section{Further recommendation for research}

Further research should focus on analysis of the young people's needs which will evolve with the next generations entering the market, such as $Z$. The studies should also include current situation of HR policy in the companies to find a gap between expectations and real situation. To ensure satisfying cooperation with Millennials, one should first understand their needs and adapt to these needs HR policies of contemporary organisations.

\section{References:}

Armour S., Generation Y http://www.riverregionchamber.net/AboutChamber/Media/GenerationY.pdf (11.01.2013)

http://www.deloitteegitimvakfi.org.tr/UserFiles/Documents/2014_MillenniallnnovationSurvey-

FULLDATA.pdf, (25.05.2015)

http://www.hrtrendy.pl/2015/12/02/rozszyfrowac-y-i-z-na-rynku-pracy, (3.12.2015)

http://www.polityka.pl/tygodnikpolityka/rynek/1601651,1,cbos-35-proc-mlodych-polakow-rozwazaemigracje.read, (06.09.2015)

http://www.polityka.pl/tygodnikpolityka/rynek/1601651,1,cbos-35-proc-mlodych-polakow-rozwazaemigracje.read, (06.09.2015)

http://www.polskieradio.pl/42/273/Artykul/1384577,Pokolenie-Y-za-10-lat-rynek-pracy-bedzie-nalezal-donich, (06.09.2015)

http://www.pwc.com/gx/en/managing-tomorrows-people/future-of-work/assets/reshaping-the-workplace.pdf, (26.05.2015)

Kosa U., Strzelec D., Zarządzanie pracownikami pokolenia Y, http://kadry.nf.pl/Artykul/8560/ ( 13.02.2013)

Portal Wiedza i Edukacja http://wiedzaiedukacja.eu/archives/76, (10.05.2015)

Sheahn P. Generation Y:Thriving and surviving with generation $Y$ at work, 2005, http://www.voced.edu.au/content/ngv23141, (11.01.2013)

Stańczyk I. Doradztwo personalne i zawodowe, Difin, Warszawa 2013

E. Babbie. The basic of social research, Wydawnictwo Naukowe PWN, Warszawa 2003

Kasalová B., Seitlová K., Seitl M. Work Environment Preferences of Generation $\mathrm{Y}$ in Relation to Attachment Theory http://web.a.ebscohost.com/bsi/pdfviewer/pdfviewer?sid=59e0aa21-247f-4f7eb157-5396707a88a3\%40sessionmgr4002\&vid=0\&hid=4209, (26.04.2016) 
Šnýdrová, Markéta Změny struktury pracovního trhu v souvislosti s nástupem generace $Y$ a dopady těchto změn na získávání zaměstnanců, Ekonomické Listy. 2014, Vol. 5 Issue 3, p18-34. 17p.,http://web.a.ebscohost.com/bsi/detail/detail?vid=2\&sid=96b7980a-b50a-4df2-b27df070188045a5\%40sessionmgr4003\&hid=4209\&bdata=JnNpdGU9YnNpLWxpdmU\%3d\#AN=101303 950\&db=bth $(26.04 .2016)$

Banerjee S. Getting 'gen y-ready', http://web.b.ebscohost.com/bsi/pdfviewer/pdfviewer?sid=94ab7beb2ed8-4c0b-9855-da6d84532c58\%40sessionmgr107\&vid=1\&hid=109 (26.04.2016)

Allen C. , Gen Y: young, gifted and slack...,Global Investor. Jul2007, Issue 204, p34-35. 2p. 1 Color Photograph., $\quad$ http://web.b.ebscohost.com/bsi/detail/detail?sid=deec61a0-5737-4e4e-8697e0eb4b441fa1\%40sessionmgr115\&vid=0\&hid=109\&bdata=JnNpdGU9YnNpLWxpdmU\%3d\#AN=265 29788\&db=bth $(26.04 .2016)$

Bhonslay M., Working Knowledge. SGB. Jun2007, Vol. 40 Issue 6, p8-12. 2p. , http://web.b.ebscohost.com/bsi/detail/detail?sid=543a7697-8f89-4e85-949a8f07f2151415\%40sessionmgr107\&vid=0\&hid=109\&bdata=JnNpdGU9YnNpLWxpdmU\%3d\#AN=253 74396\&db=bth $(26.04 .2016)$ 